\title{
Bays International Private Limited: Evolving Through Market Dynamics
}

\author{
Saad Jamal Farooqui*, Jawaid Qureshi**, \\ Madiha Zeeshan ***, Kamran Abmed Soomro****
}

\begin{abstract}
Bays International was incorporated in 1996. Over the years it faced numerous challenges including high employee turnover (particularly salesforce), limited expansion capabilities, low penetration in semi-urban markets, high operating expenses like rentals, increasing duties (on luxury products), low cash-flows, low budgets for advertising and marketing as compared to competitors, less awareness amongst consumers, volatile consumer preferences (especially by millennial), weak brands' loyalties, counterfeits/fake products, smuggling and infiltration from grey channels, the high number of foreign and local chains entering the market, price war especially with local chains, and uncertain political situation. Four interviews were conducted from management and two interviews from ex-employees. Moreover, a lot of open access documents of the company were reviewed. The pertinent literature review also revealed interesting insights about emerging consumer trends and the cosmetic industry along with interviews of some marketing directors of leading global brands. Bays leadership believes that key parameters are improving over time. The case covers how the company maneuvered itself since its inception and launched numerous other brands targeted towards different segments of the society, to steer towards growth in changing internal and external environment. The case is based on a scenario when there is yet another increase of taxes by the government in 2019 and presents troublesome situations to branding cum marketing strategy for the company to consider.
\end{abstract}

Keywords: Cosmetic Industry, Market Dynamics, Branding and Marketing Strategy JEL Classification: $M 310$

\section{INTRODUCTION}

It was December 2018, when Mr. Sohail Ahmed, chief executive officer (CEO) of Bays International, just finished reviewing the plan for 2019. The company was incorporated almost

\footnotetext{
Correspondence:

*Student, Shaheed Zulfiqar Ali Bhutto Institute of Science E Technology, Karachi

**Assistant Professor, Shaheed Zulfiqar Ali Bhutto Institute of Science E Technology, Karachi

***akecturer, Shaheed Zulfiqar Ali Bhutto Institute of Science E Technology, Karachi

*****Assistant Professor, Shaheed Zulfiqar Ali Bhutto Institute of Science E Technology, Karachi
} 
25 years ago, and the road was rocky to reach success - definitely not smooth. Changes had to be inculcated in marketing and business strategy to make a success story. In November 2017, the government of Pakistan through a mini-budget announced an upward increase in taxes for the luxury goods, while such taxes also escalated in subsequent years too. Sohail Ahmed reviewed strategies to incorporate with his team and was determined to address the situation in detail and reach a conclusion. In general, over the years it faced numerous challenges including increasing duties (on luxury products affecting their sales and necessitating price escalation), low cash-flows (negatively affecting its marketing programs), high employee (particularly sales team), limited expansion capabilities, low penetration in semi-urban and rural markets, high operating expenses like rentals, low budgets for advertising and marketing as compared to competitors, less awareness amongst consumers, volatile consumer preferences (especially by millennial), weak brands' loyalties, counterfeits / fake products, smuggling and infiltration from grey channels, the high number of foreign and local chains entering the market, price war especially with local chains, and uncertain political situation. Re-devising it's brand architecture and marketing strategy for exploiting ever-changing social trends seemed a heavy challenge.

\section{Cosmetic industry Pakistan}

Consumers are influenced by 360 degrees of marketing influence which led to the evolution of beauty products for both males and females. Skincare products had the highest market share in the beauty industry including products and services related to hair, nail, perfumes, and colognes, skin, cosmetics, antiperspirant, feminine cleaning, oral hygiene, etc. The growth of the beauty industry depends on a variety of factors including the growth of small salons, demographics changes, and growing avenues of the growing fashion industry. The cosmetics industry flourished in urban, semi-urban, and rural territories of the country, and over time, the awareness about quality brands rose substantially. In contrast, globally rapidly thriving economies like Brazil, Russia, India, China (BRIC), etc., enjoyed approximately $25 \%$ of the market. Furthermore, markets like India have witnessed an increased number of international players. The country which initially remained women-oriented, today has started concentrating on male grooming also. This changing trend has resulted in a large number of unisex salons (Bays International, 2019).

The global personal care market size stands at almost US $\$ 455$ billion nourishing at the rate of $6 \%$ per annum (Euromonitor, 2018). Keeping in view the current scenario where one could find beauty salons in every corner of the small and large city of Pakistan. The beauty segment was yet not covered as a major business in the eyes of the authorities. Other business growth indicators were the influx of international brands in various areas in leading retail stores and wholesale markets. The demand and consumption of the personal care category evidence a record growth trajectory domestically with an annual market size of US $\$ 1.7$ billion moving upward at the rate of $15 \%$ per annum. However, industry experts estimate that the actual growth is $20 \%$, but some share goes to black market channels comprising smuggled products and brands, grey market goods, and counterfeit brands (Shaikh, 2018).

Since opening a beauty salon did not require any license, there was no information bank or database available on the market size. Also, individuals were catering to small communities and were part of the underground economy. The cheery on the top is that in Pakistan Economic Survey, there was no section that discussed the cosmetic industry and the growing trends in the beauty industry (Bays International, 2019). 
The only factor that the governmental bodies are concerned with is to increase taxes since the cosmetic industry was considered as the luxury industry. Bays management believes that there were no policies to encourage the local businessman to flourish their business instead, but taxes are regularly implemented on trading houses and manufacturing plants. This did not pinpoint a sudden downturn in economic performance but also decreasing employment opportunities. Renowned personalities were cautious to share their views on business trends.

A competitive environment was heavily dominated by global players but many domestic players were also taking some market share. Among them, the prominent ones include Mac, Revlon, Loreal, Medora, Estee Lauder, Shiseido, Neutrogena, Body Shop, Saffora, Maybelline, Clinique, Etude, Oriflame, Urban decay, Covergirl, Avon, Boots, NARS, Unilever Pakistan's Fair and Lovely brand and its other brands, Colgate Palmolive, Johnson and Johnson, Procter and Gamble (P\&G), Reckitt Benckiser(RB), Saeed Ghani, Tibet, Kala Kola, Hashmi, and J. Cosmetics and Fragrances, Luscious Cosmetics, Odho (by renowned TV celebrity, Atiqa Odho with Ariqa O brand), (Business Recorder, 2010; Pakistan Cosmetics Manufacturers Association, 2019). On the other hand, many less recognized imported brands to domestic brands also took some share in the business. Some domestic brands like Faiza Beauty Cream incurred huge outlays on advertising to attract masses of middle and lower classes and take a reasonable chunk of market share. In 2017, a seminar on the beauty industry was jointly organized under the China-Pakistan Economic Corridor (CPEC) banner by cosmetic of All-China Federation of Industry and Commerce to explore trade and business opportunities in Pakistan including the beauty sector. In the seminar, it was revealed that several projects are being considered under the umbrella of the CPEC framework for the vision on "one belt one road (OBOR)". Not only this but a lot of Chinese businessmen showed keen interest in setting up their business units in Pakistan which was not only productive for creating more employment opportunities but al in improving cordial relationships between the two countries (Bays International, 2019).

\section{Strategic importance of Pakistan}

Pakistan being a developing nation has a young and growing population of a diverse background of over 200 million-plus people who are receptive to creativity, innovation, and products with good quality products. The country has seen internal political disputes and low levels of foreign investment since the military rule ended in 2008. The country still is an underdeveloped nation and has witnessed a lot of bureaucracy, terrorism, and corruption. The weak labor laws and intellectual property rights violation has been a hindrance for many foreign investors. Nonetheless, the country has the 9th largest English speaking population along with a large educated workforce. Moreover, it is considered as an emerging market having a lot of potential for growth in various sectors. This greatly reduces the labor and production costs because of the workforce's ability to acquire new skill sets through training and development on business operations and efficient cum effective management practices in line with global benchmarks of quality and service yardsticks (Bays International, 2019).

The year 2014 was a critical year when the government in collaboration with the International Monetary Fund (IMF) implemented economic reforms. Also in the same year, Pakistan qualified for the European Union (EU) - Generalized System of Preferences (GSP) plus award, which allows countries to pay less or no duties on exports to the EU. The same year also witnessed that Pakistan and China agreed on the 'China-Pakistan Economic Corridor' 
(CPEC), which started at US $\$ 58$ billion financial programs targeted towards the energy and infrastructure projects in Pakistan (Bays International, 2019).

\section{Bays International}

Bays International was formerly known as Mehran Enterprises; it launched several renowned products in the beauty industry. The vision has always been to deliver a full 360 degree of service for the beauty industry. This vision resulted in the business model which expanded or diversified into other business areas to expand and penetrate Pakistan. They are committed to deliver the best cosmetic brands for their consumers. Headquarters for Bays International is in the UK. The company has been creating a distinguished brand image in the beauty industry since 25 plus years. Its benchmark has been to surpass its competition in the beauty industry in Pakistan. With a presence through offices in all the major towns and cities, the company has a team of a professional network of distributors and a continuously trained sales force. It has focused on visibility in international modern trade (IMT), local modern trade (LMT), and general trade (GT). The presence of their products is ensured at all times (Bays International, 2019).

Bays International was participating immeasurably in the development of the beauty industry in Pakistan. For instance, "Makeup City" is a one-stop cosmetics specialty store concept. It offers its customers a wide range of premium quality products besides best customer services, with over 30 retail stores in all the major cities. "Bays Lingerie Studio" - is another venture of Bays International in the fashion retail which catered to personal boudoir collection for females' undergarments. Femina Hair and Makeup Institute was a pioneer in makeup related training, where well-groomed beauty experts in beauty and fashion fields impart training to professionals and potential new entrants to the industry (Bays International, 2019).

\section{Mission and vision}

The mission and vision of bays international are derived from the core values including sustainability, integrity, teamwork, passion, diversity, and respect.

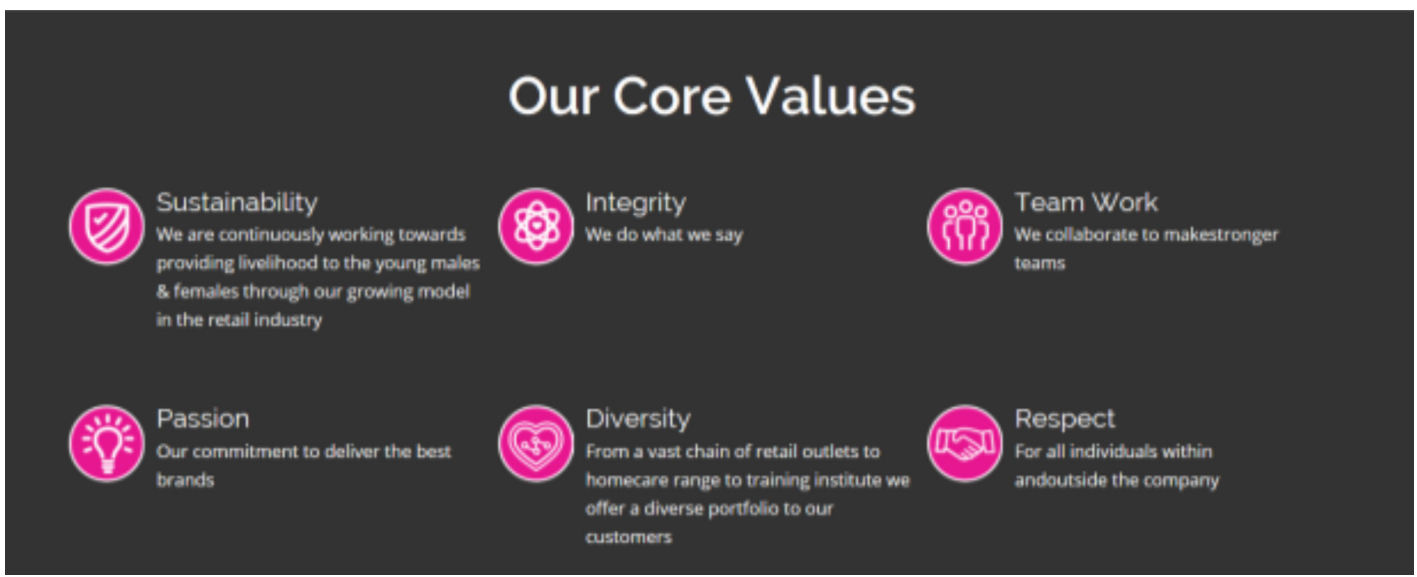

Figure 1: Core values of Bays International; Source: Bays Internatinal (2019) 


\section{The team at Bays International}

The team at Bays International was relatively young. There had been a lot of turnover in the past. CEO, Mr. Sohail Ahmed started the company but had other businesses to look after as well. Figure 2 below outlines the organogram of the company. The CEO is assisted by the managing director (MD). Under them is a huge team mainly comprising heads of various functions/departments and their aides. They comprise the head of marketing (supported by brand managers, services marketing, and digital marketing staff), heads of sales, supply chain, human resources (HR), finance, and information technology (IT).

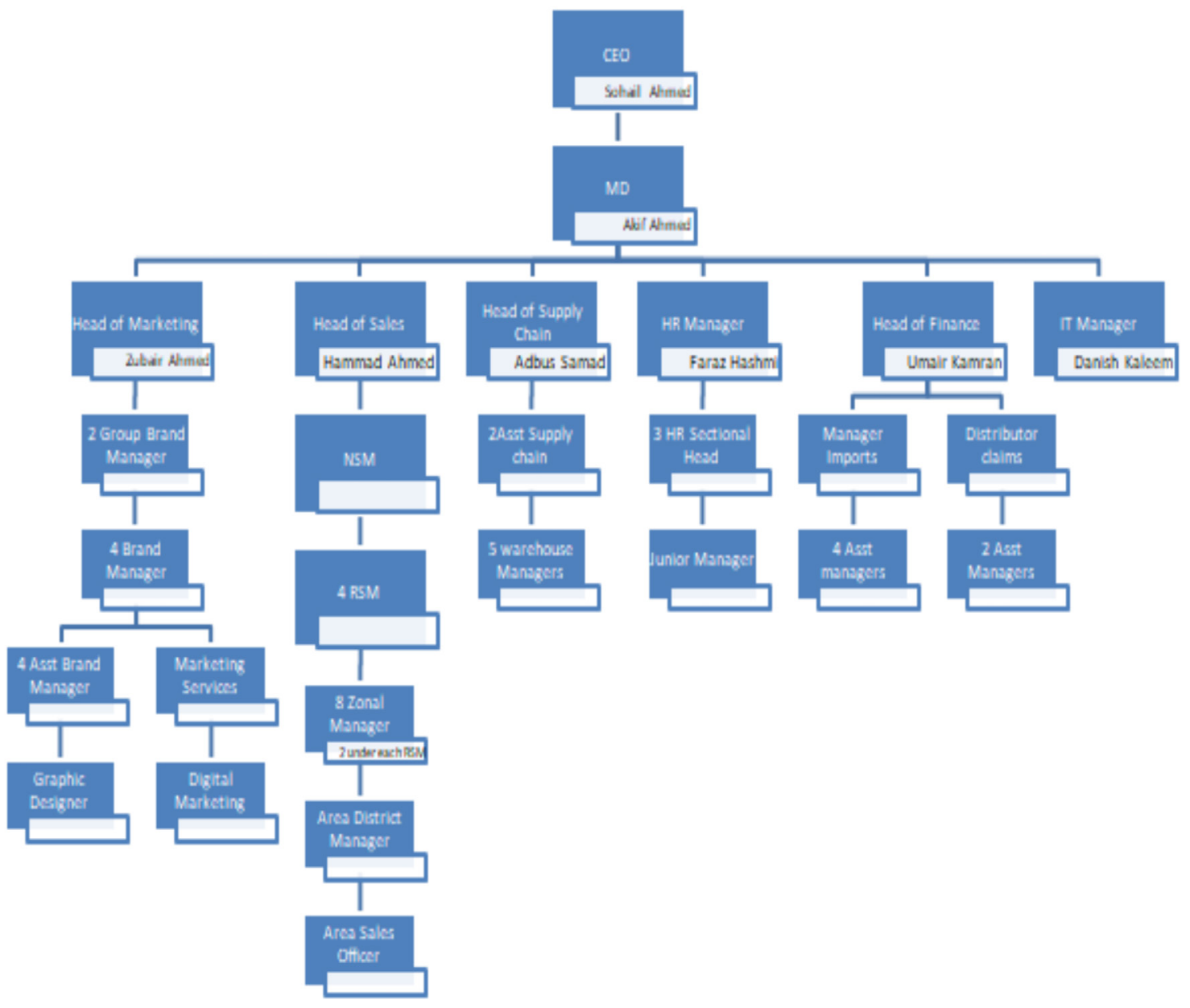

Figure 2: Organizational Chart of Bays International; Source: Bays International (2019)

\section{Sales trends and market performance}

Over the years, Bays International kept on thriving as its sales revenues kept on nourishing. This could not have been possible without the apt support of marketing programs to establish its brands. The continuous progress of its salesforce, beauty experts at its outlets and institutions, supply chain network, and brand expansion in several territories assisted toward establishing its customer loyalty and brand equity. Figure 3 beneath portrays its sales graph from the year 2000 to 2017. It can be observed that the sales increment was quite smooth and gradual, reaching a 
remarkable value of approximately PKR 2.5 billion.

Bays International operated on a $40 \%$ gross margin. Since most products were manufactured in the United Kingdom (UK), while others were franchise brands. There was a high import duty on these products. Furthermore, its subsidiaries including Makeup City, Bays Lingerie Studio (BLS), and Femina Beauty Academy, had retail operations, which dedicated a sizable amount of outlays for managing these platforms, inclusive of rents, utilities, and packages of dedicated staff (Bays International, 2019).

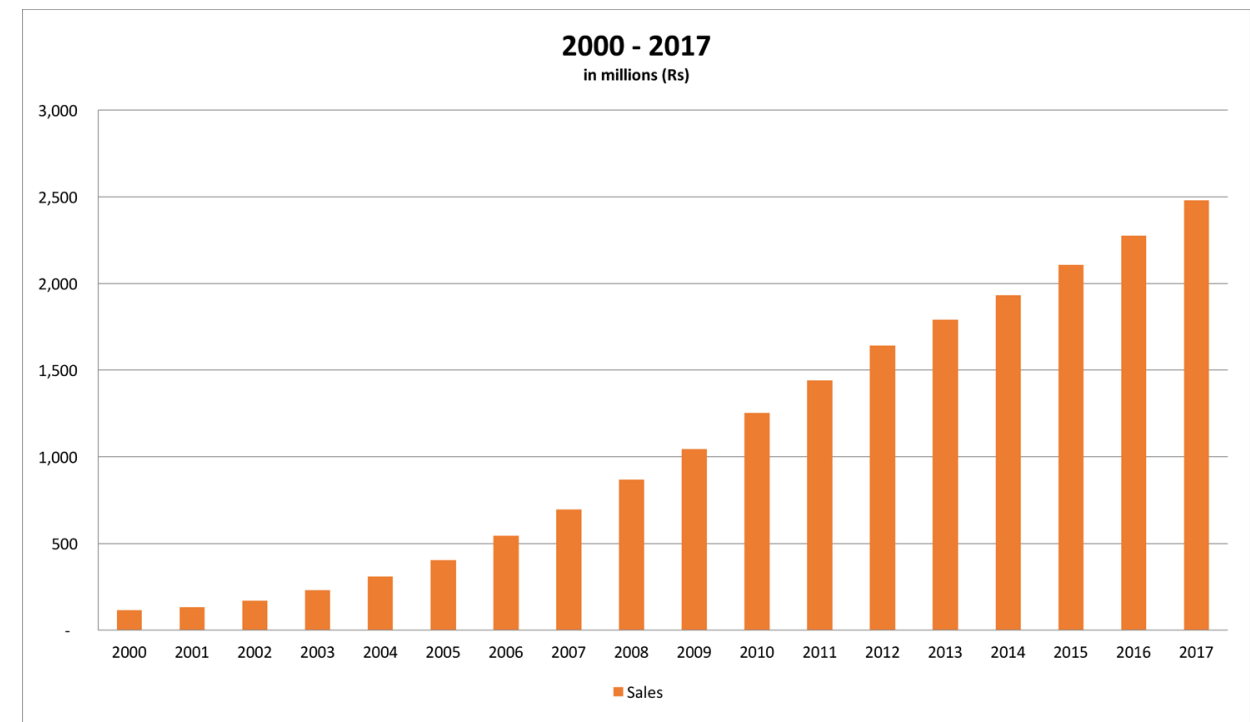

Figure 3: Sales Trend of Bays International; Source: Bays International (2017)

\section{Retail divisions at Bays International}

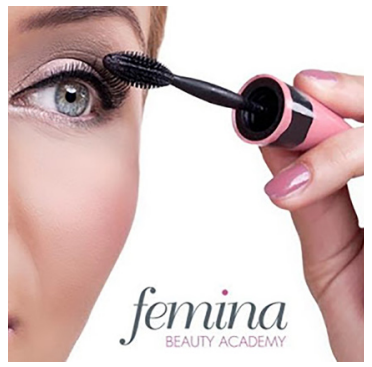

Femina Beauty Academy: Launched in 2003 in Karachi, with the aim to establish itself in Asia as one of the most effective beauty programs.

Highly trained experts lead the team at Femina Beauty Academy. It aims to provide training to industry's beauty professionals across Pakistan. Today it has 10 academies working nationwide.

Picture 1: Femina Beauty Academy
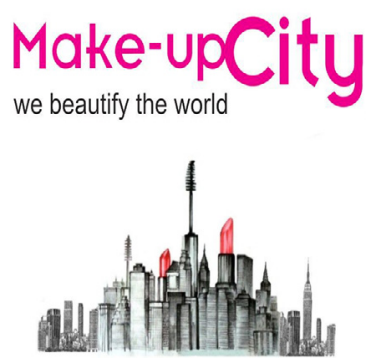

Make-up City: A retail concept store launched in 2012 and pioneered in bringing a one-stop beauty shopping experience of international beauty and personal care brands. Its slogan is: 'We beautify the world'. Each of the products, from beauty to personal care was manufactured keeping an unwavering focus on the exquisite caliber. Outlets of makeup city were located in all major cities of Pakistan.

Picture 2: Make-up City 


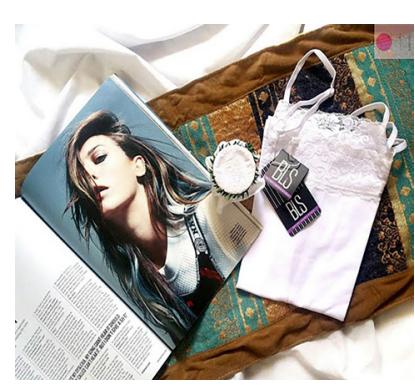

Bays Lingerie Studio (BLS): Launched in July 2015, BLS was a fashion concept store providing everything needed for the personal boudoir collection. With its first flagship outlet in Xinhua mall - Lahore, BLS had opened seven outlets nationwide. Bays International strategized to expand the concept (of BLS) nationally.

Picture 3: BLS - Bays Lingerie Studio

\section{Packaging / Filling department}

The packaging department was located in Northamptonshire, UK. The company had a specialized, thoroughly reliable, and flexible filling and packing facility with an outstanding quality, which was backed by over 25 years of experience. A wide selection of quality services at Bays International (as displayed in Table 1 underneath) included bulk packing, bottle filling, cartridge filling, tube filling, capping, labeling, and so on.

Table 1. Services of the Packaging Department

\begin{tabular}{l|l}
\hline Bulk packing & Sachet filling \\
Bottle filling & Shrink sleaving \\
Cartridge filling & Varied ration filling \\
Tube filling & Quality fulfillment and rework \\
Capping & Syringe filling \\
Labeling & Clean room \\
Vile filling & Coax cartridge \\
Thermal label printing & Foil sealing \\
Bagging & Product mixing \\
Ink jetting and date coding & \\
\hline
\end{tabular}

Source: Bays International (2019)

\section{Customization of products}

Bays International recognized that rather than producing standardized products only for the world market and mass marketing, customization was required because standardization was like providing a 'one size fits all' approach. The company had launched a wide variety of products. These products were grouped/bundled together under different categories, as illustrated in Table 2 underneath.

Table 2. Product Categories of Bays International

\begin{tabular}{|c|c|c|}
\hline Makeup & Haircare & Cosmetic (skincare) \\
\hline Makeup remover & Shampoo & Peel off mask \\
\hline Cleansing & Hair color & Powder form \\
\hline Toning & Hair treatment for: & Derma fleece \\
\hline Scrubbing & Unhealthy & Wash off \\
\hline Treatment & Falling hair & \\
\hline
\end{tabular}


Face massage

Face mask

\section{Wary hair}

Rebonding

Sunblock

Styling product

Source: Bays International (2019)

Several market research companies have classified beauty and personal care products distinctively in Pakistan, as illustrated in Table 3 beneath (Allied Market Research, 2019; Euromonitor, 2019; Market Research, 2019). Skincare, haircare, and make-up constitute three broad categories.

Table 3. Beauty and Personal Care Products Categories in Pakistan

\begin{tabular}{ccc}
\hline $\begin{array}{c}\text { Classification by Allied Market } \\
\text { Research }\end{array}$ & Classification by Euromonitor & Classification by Market Research \\
\hline Makeup/color cosmetics & Baby and child-specific products & Eye make-up products \\
Haircare products & Bath and shower & Lip make-up products \\
Deodorants & Color cosmetics & Make-up and skincare powders \\
Skin and sun care products & Deodorants & Pedicure and manicure products \\
Fragrances & Depilatories & Other make-up and skincare products
\end{tabular}

Others: Fragrances, Hair care, Men's

grooming, Oral care, Sets/Kits, Skin

care, and Sun care

Sources: Allied Market Research (2019); Euromonitor (2019); Market Research (2019)

\section{Brand management strategy}

A strategic brand management process was followed by Bays International. Starting from brand positioning (of high quality, superior brands), linked with its vision and mission to consumer insights and market research, right segmentation and targeting to suit the needs of various groups of consumers helped it attain its strategic objectives. Moreover, research and development (R\&D) based product development and filling/packaging, distribution, and leading to advertising, media management, consumer promotions, and digital marketing aids supported its marketing programs. Sales forecasts and revenue modeling were regularly conducted. In addition, it garnered market intelligence data and applied analytics tools to be aware of the rivals' strategies, safeguarding it from their assaults, and keep itself abreast of competition. Eventually, it continually tracked its brands' performance and matched them brand success metrics, ranging from brand awareness, positive word of mouth communication to sales, profitability, territorial expansion, brand extensions, etc. Some of its digital marketing metrics comprised: brands searched, pages viewed, click-throughs, likes, comments, queries, placing orders, and so on.

\section{Brands at Bays International}

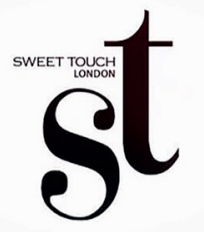

Sweet Touch: Developed as a premium, contemporary brand targeted at young women with a flair for fashion. The brand received rave reviews from beauty experts. 


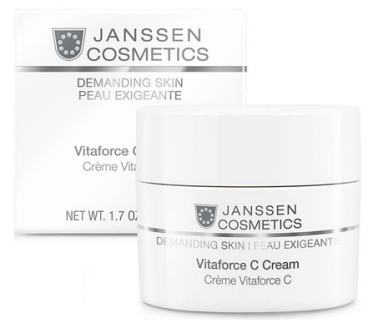

Picture 5: Janssen

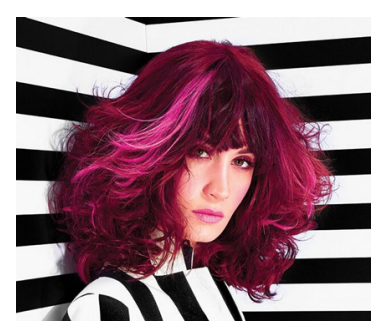

Framesi (professional hair fashion): A market experience of over 70 years, the brand had been stimulating the creativity of hairdressers around the world through designing innovative products. Being an Italian hair care brand with a strong presence throughout Europe and other key markets, it was famous for creating new trends in hairdressing.

Picture 6: Framesi (professional hair fashion)

femina

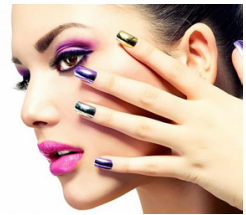

Femina (cosmetics): Launched in 2009, in the cosmetics category, the brand is manufactured in Europe. The brand delivered value, quality, and provided an instant gorgeous look at affordable prices. The price list is available in Exhibit $\mathrm{C}$.

Picture 7: Femina (cosmetics)

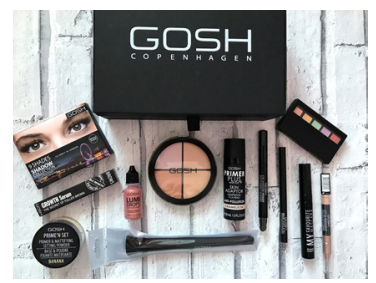

Gosh (cosmetics): The core values for this brand comprise: quality in all brands, creativity in approach, and affordable prices appear as the signature of the broad appeal of the brand. Gosh is a leader of the latest trends and styles and continues to develop top quality products to meet the needs of their consumers.

Picture 8: Gosh (cosmetics)

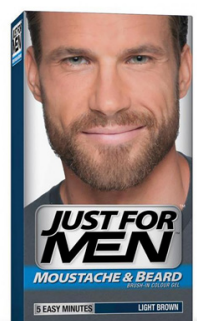

Just for Men: The brand believed that men should feel free to select their appearance with or without grey hair. The brand enjoyed the first position for men's hair coloring and treatments. Multiple awards were received from all over the world.

Picture 9: Just for Men

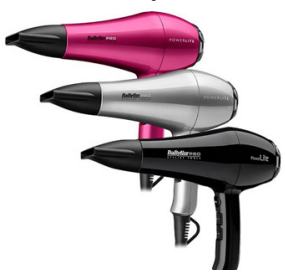

Babyliss pro (styling tools): The key features of Babyliss include: technical sophistication, professional expertise, and innovative designs. For hairdressers and beauty therapists, the product range included: curlers, hair dryers, shavers, hair straighteners, and grooming products. 


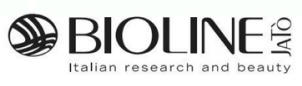

Bioline: The Italian skincare brand, Bioline was established in 1979. The brand has a reputation as one of the most trusted global beauty brands.

\section{Picture 11: Bioline}

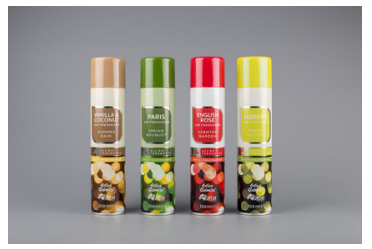

Fragrance Lotion Admire: The brand has a 40-year history in the Middle Eastern markets, with roots from traditional English brand. With its iconic and distinctive 'coach and horses' logo, the brand has been developed as an iconic "Paris" scent. Research teams continuously develop fresh aromas, as currently available in seven unique fragrances.

Picture 12: Lotion Admire

\section{Competitive landscape and emerging consumer trends}

As an external force on the business, competition is the most significant. Healthy competition is a good sign for the business. Competitors (local and international brands) were exposed to a variety of above the line and below the line (ATL and BTL) tools, which enabled them to penetrate the market through regular launches and campaigns for promotion. Numerous branded and unbranded companies operating globally were present with high quality, genuine brands to various companies with sub-standard products to counterfeit brands. The importers usually provided products on credit terms of 60-90 days, with a good retail margin. Attractive margins, make it a good incentive for the retailer to push the products. Also, numerous competitors mean easy brand switching for consumers as well as retailers and wholesalers.

For a healthy business, we need healthy competition. Bays International realized that Pakistan is a hypercompetitive market. As the import of items is not restricted, and many individual players are launching their brands and flooding the marketing with international brands. Also, the grey channel and counterfeit products of Bays International's product is a competition for the company. This is in addition to the other global brands that were present in the local market and advertising through numerous channels and mediums. Thus, Bays International was challenged to achieve its top-line and bottom-line targets. The objective to serve customers under intense competition appeared a great pressure for salespeople.

Domestically, consumers have become more conscious to their personal care needs. Urbanization, rising per capita income, women's increasing share in the job market, and trends of beauty, fashion, and changing lifestyle to the cultural acceptance of aesthetic appearance have substantially contributed towards the fast growth of personal care products. Ever-escalating access to the internet and smart mobile phones to populace living in urban, rural, and even farflung areas of the country have magnificently risen awareness and sales of beauty and personal care products. Moreover, Pakistan is fortunate to have a nearly $60 \%$ youth population with an average age of 23 years. The youth bulge seemed well-motivated towards a stylish look and grooming (Shaikh, 2018).

Regarding the query about rivalry and threat of local players to global players, Salar Farooki, Marketing Director, L'Oreal Pakistan, expressed that "the influx of more local players can only raise awareness and offer more choice to consumers. In Pakistan, the penetration of most 
formats within the beauty category is still quite low, and therefore, there is plenty of room for all kinds of local and international brands to carve out a niche across geographies, price points, and propositions." The beauty experts believe that today's consumers look for product quality, features or ingredients, and brand name cum image, while the price is a secondary concern for them. That is why they believe that personal care items fall inflation resistant.

Price sensitive consumers switch to mostly less differentiated products like soaps and toothpaste. However, masses in the poor and middle strata of the society prefer buying smaller stock-keeping units (SKUs), minimize consumption, or switch to locally available affordable brands. Humayun Farooq, Marketing Director, Reckitt Benckiser (RB) Health, summed it: "As spending on skincare and hair-care products are factored within the monthly grocery bill for this group when prices go up, customers are forced to downgrade to smaller SKUs, reduce consumption or if possible, switch to local options that are more affordable" (Shaikh, 2018). In the shampoo category, small and very affordable sachet packs are the perfect example of the bottom of the pyramid (BOP) marketing by renowned brands.

Established and heritage brands enjoy greater brand awareness, wide distribution and dealership network, digital brand engagement with consumers, and a loyal consumer base. The latest consumer trends reflect inclination towards quality, natural products, organic ingredients, Halal certification of beauty products, containing ingredients that appear permissible under Islamic laws, as Muslim consumers worldwide worry about pig fat-based gelatin and other such ingredients (Shaikh, 2018).

'Conscious fashion' has become a buzz phrase. Asima Haq, Director, Personal Care, Unilever Pakistan stated that "Pakistani women are looking for solutions with natural goodness because they have grown up with totkas (i.e. indigenous formulas) about how herbs boost beauty. The modern consumer wants a specific benefit (fairness, for example) through natural elements." Fair and lovely Herbal brand as part of the brand extension of its parent brand Fair and Lovely substantiates such emerging trends. Muslim communities or consumers worldwide have been demanding Halal certified (i.e. the ingredients permissible under Islamic laws) beauty products. In the Asia Pacific region, the demand for such products exceeds the two-thirds quantity of total supply (i.e. 70+ \%). All-in-one or multi-functional products have been attracting marvelous demand. Whitening and beauty cream in one pack and shampoo with conditioner treating dull, dry, falling, and grey hair, and making them silky and shiny fall some such perfect examples. Men's fashion for the personal care category also observes rapid inclination. Their product portfolio comprises shaving kits, shampoos, cleaning soaps and liquids, body washes, creams, powders, hair oils, deodorants, and fragrances (Shaikh, 2018).

The cosmetic industry has also witnessed a surprisingly new trend that relates to activism. Branding gurus call it 'brand activism', where a brand raises a social cause and consumers patronize it in the broad interest of society. Such causes are conveyed through television commercials (TVCs) and integrated marketing communication (IMC). Veet and Lux brands, for instance, celebrated various events reflecting brand activism, which received an overwhelming response from consumers. Ponds beauty cream celebrated it by highlighting high-achieving women in society about corporate, industry, media, civil society, and other sectors. Its purpose was to position itself as a very responsible brand, which received consumers' endorsement and brand loyalty (Shaikh, 2018). 
The consumers of beauty and personal care products also visit dermatologists or skincare medical doctors, who prescribe various medicines and medicated soaps, shampoos, creams, gels, etc. to them. Some such specialists provide cosmetic and plastics surgery services to them. Some consumer healthcare companies also own medicated soaps, liquid washes, shampoos, etc.

\section{Hazardous effects of cosmetics}

The ingredients of various cosmetics products contain several chemicals and metals. The hazardous effects of cosmetics contain ordinary ailments like headaches, allergies, and even hormonal disturbances. Such side effects are portrayed beneath in Table 4. (Baran \& Andre, 2005; Kumari, Pandita, Poonia, \& Lather, 2017; Maithili, Anuradha, \& Nupur, 2015; Mohamed, 2015; Tejal, Nishan, Amisha, Umesh, Desai, \& Bansal, 2013; Zulaikha, Norkhadijah, \& Praveena, 2015). A bio-physics scientist at Oxford University, UK, Dr. Bilal M. Qureshi warns, "Beware of the cosmetics as some base powders of makeup contain nearly five thousand chemicals. It calls for greater awareness in masses, and they should carefully choose their brands, especially those containing natural, organic, and safe ingredients."

Table 4. Harmful Side Effects of Cosmetics

\begin{tabular}{lc}
\hline \multicolumn{1}{c}{ Effects } & Source of Study(ies) \\
\hline $\begin{array}{l}\text { Headaches, hair problems, acne, skin allergies, eye infections, } \\
\text { infertility, premature aging, hormonal imbalance, cancer, } \\
\text { and skin discoloration }\end{array}$ & Daily Hunt (2019) \\
$\begin{array}{l}\text { Acute toxicity, percutaneous absorption, skin irritation, eye } \\
\text { irritation, skin sensitization, photosensitization, subchron- } \\
\text { ic toxicity, mutagenicity/genotoxicity, and phototoxicity/ } \\
\text { photoirritation }\end{array}$ & Maithili, Anuradha, E Nupur (2015) \\
Symptoms of allergy including red eyes, itchiness, contact \\
dermatitis, eczema, and can be life-threatening reaction \\
called anaphylaxis
\end{tabular}

Sources: Daily Hunt (2019); Maithili, Anuradha, \& Nupur (2015)

\section{Branding strategy and marketing programs}

Over the years there has been an upward demand from the customers, who enjoyed access to the internet to order online. The core challenge for the company has been to continually engage the customers and provide them with the best of the best options and variety. Bays International imported high quality, innovative brands with a huge variety under various high-demand segments, priced them competitively, used their 160+ distributors network for delivering them nationwide. Hence a change in the structure of the company was implemented to operate their product retail outlets by the name of Makeup City. With eighteen outlets nationwide from which four were in Karachi (the largest metropolitan territory of the country), the retail platform provided demonstration and availability of a complete range of products. The retail price from the company outlets was almost the same as in the open market and the margin for distributors was retained by the company to cover their expenses of rentals, salaries, utilities, etc. for operating each outlet and meeting customers' expectations.

Sales representatives were groomed at the 'Femina' training institute, which was another business concern of Bays International. The response rate and knowledge of the sales team were appreciated by the customers who look for professional help when it comes to makeup. 
The breadth and depth of information communicated by the salesperson helped the customer in customization of their need for the product/service offerings. Customers did not feel a gap in the internal turnover of the company and continued their visits are as per routine. The key factor being that salespeople were continually being upgraded and avoided becoming obsolete in knowledge terms.

From another angle, salespeople had a better perspective of customers and delt them more appropriately and supplied consumer insights and changing market dynamics to the company, and thus became the eyes and ears of the company. Bays international also ensured utilizing them as a 'listening post' and monitored both the market and rivals operative in the market. The management specifically the marketing and sales heads conduct regular market research and visit the market to understand the customers and their requirements. The findings were shared with the management every month.

With the easy accessibility of information through the internet, morning shows on TV, beauty parlor experts, catalogs, etc., customers were increasing their awareness about the brands of Bays International. This rose pressure on sales people to keep on upgrading their technical knowledge. Bays International continuously strived to incorporate the best available technical, technological, and product expertise for their sales people in order to satisfy the customers. FAQs (Frequently Asked Questions) sessions were made regularly for the company representatives who interacted with customers and buyers so that they can answer adequately.

It has been witnessed that customer expectations enhance and they prefer to purchase from company-managed outlets rather than from the general trade, which is catered by the distributors.

To effectively serve these diverse customers, different level of communication is required for different products, services, and applications. Key account managers and trade marketing managers had to disseminate a varied level of information to a different set of people. Recently the price hike by the government was to be communicated across the board. This was easy for Bays International as it was not the only company increasing price. Because of a strong relationship of salespeople with a trade channel, the price change was effectively communicated.

In the early years of Bays International, business-to-business (B2B) activity took place. However, sales volumes increased and the company moved to the business-to-customers (B2C) model and the company launched Makeup City and BLS. The decision was influenced by renting out new locations, hiring staff, maintaining inventory software for retail level, training, and developing of own staff, etc. Salespeople were able to guide the general trade to direct their customers.

Bays International, therefore, tried to adapt to different variations of selling situations in a rapidly changing environment. It was planning to launch a customer loyalty card to focus on the 'Customer Lifetime Value' (CLV). In a competitive environment, it strategized allocating scarce resources to attain a better CLV, where the customers who had the potential to switch to competitive brands can be retained. The customer relationship management (CRM) technology available with the company was capitalized by salespeople for long-term fruitful relations with customers for building customer loyalty and brand equity as an effective result of sales and marketing activities. 
When Mr. Ahmed (CEO) observed remarkable success for Makeup City, he decided to introduce his training center as Femina Beauty Academy in 2003. Since this is a very femaleoriented place and certain female requirement of privacy was required, almost $98 \%$ of the staff was female. Most of the females were in 'hijab' or veil, due to their family orientation in Muslim countries like Pakistan. Also, females required privacy when in a learning session, hence no men were allowed in the Academy, except guards or peons.

\section{Adopting Modern Technology}

To satisfy the rapidly increasing customer expectation, Bays International was employing faster technological solutions. For instance, for distributors, the software was used to track their basic information and analyze their sales trends. Bays International, over the years, created the reputation of a big corporate brand demanding advance payment from its distributors. This means there was no credit sale. This was because the products were in high demand, but as consumers pull and trade push, the company did not offer any credit terms. Discounts were seldom offered and that too on slow-moving items. The sales tracking system provided a customized and long-term business solution. Seasonality and sales cycle were tracked and salespeople were able to communicate with distributors in real-time.

The new version of the CRM (Customer Relationship Management) system was in process of finalization stages. The system could generate a customer-specific identification card and record sales per customer so that relevant product launches were communicated to the right target audience. Such analysis appeared a big step towards customer analytics by understanding and assessing who buys what, why, when, how frequently, which brands in combination, and with what mode of payment (i.e. cash or credit card, etc.). Also, the system would provide a platform to have a steady communication medium with customers. Further, CRM helps the sales team and such automation is called an SFA (Sales Force Automation) system, which requires sales people to standardize their sales data on a network. The need for such a system was not only to track the sales trend and target achievement of each salesperson but also since there is a high turnover of employees (particularly salesforce) in the company, it did not want to lose out key accounts and customers.

Any new system would face resistance and so will the SFA with Bays International. The company has started a system of KPM (Key Performance Management). The salary is being linked to this KPM and evaluated by the line manager for each sales person. In 2019, the system is lagging, but slow implementation is taking place.

The company witnessed that there has been turnover amongst the best salespeople. This was alarming because the company needed to be aware of the reason behind turnover. Usually, the sales people were offered a relatively better salary and benefit at other organization, but sometimes its aggressive growth target led to frustration among salesforce, leading to a turnover.

Regular monthly meetings were held and target versus expectations were aligned amongst all the departments: marketing, sales, supply chain, finance, training, etc. New product launches and innovations were discussed and brought to the knowledge of all concerned through a common platform. Usually, the regular coordination amongst the department was an ongoing process. Departments, specifically sales and marketing continually need to adhere to changing internal shifts to an uncertain external environment, and performance is always a challenge. Changing 
market dynamics are ultimately a reflection of the behavior and culture of the organization. Bays International consciously tried to adapt to changing dynamics. One adaptation was the creation of a key account department to focus on high-value clients.

\section{The department review meeting}

Mr. Sohail Ahmed, the CEO chaired the monthly review meeting. Soon after the pleasantries were exchanged amongst the participants, he laid down the question of the day. "Let us not haste in concluding to re-launch our brands with new price tags," said Mr. Ahmed. "We need to discuss in detail our market scenario and our internal capabilities." Marketing and sales executives debated their point of view of launching new products amidst the competitive scenario, which finance and supply chain departments debated on the stock availability at primary and secondary levels.

At that moment the telephone bell rang and the secretary of Mr. Ahmed informed him of a scheduled meeting with the product development team. "The team needs to reach a conclusion and I need an answer by today evening to sign off with our strategy for 2018-19", said Mr. Ahmed. The team agreed that they have made some progress and they agreed that the matter required further attention and would submit their recommendation by close of 2018-19.

\section{Way forward}

Mr. Sohail Ahmed, CEO of Bays International pondered that the branding and marketing strategy for 2019-20 should address the front burner issues like increasing duties (on luxury products affecting their sales and necessitating price escalation), low cash-flows (negatively affecting its marketing programs), high employee turnover (particularly sales team), limited expansion capabilities, low penetration in semi-urban and rural markets, high operating expenses like rentals, low budgets for advertising and marketing as compared to competitors, less awareness amongst consumers, volatile changing consumer preferences (especially by millennial), weak brands' loyalties, counterfeits / fake products, smuggling and infiltration from grey channels, a high number of foreign and local chains entering the market, price war especially with local chains, and uncertain political situation or regulatory environment. He worries about several additional issues too like re-devising its brand architecture and marketing strategy for exploiting ever-changing social trends by outsourcing the services of some professional brand consultants. The marketing teams were demanding budget for market research, collecting consumer insights from digital marketing analytics inclusive of web analytics, social analytics like Instagram, Facebook, YouTube, and Google analytics, etc., gathering market intelligence about rivals' offering and strategies, re-targeting wholesalers, retailers', supermarkets, and beauty parlors to men's saloons, etc. Having its manufacturing plant instead of importing brands, producing customizing products, offering organic, Halal-certified, multifunctional brands for all sexes, age groups, and skin to hair types were other grave concerns.

\section{REFERENCES}

Allied Market Research. (2019). Pakistan cosmetics market. https://www.alliedmarketresearch. com/pakistan-cosmetics-market

Baran, R., \& Andre, J. (2005). Side effects of nail cosmetics. Journal of cosmetic dermatology, 4(3), 204-209. 
Bays International. (2018). An Overview Of Bays International. http://www.baysinternational.com

Bays International. (2018). History Of Bays International. http://www.baysinternational.com/history

Bays International. (2018). Babyliss Brands. http://www.baysinternational.com/brands/babyliss-pro_4

Bays International. (2018). Bioline Brands. http://www.baysinternational.com/brands/bioline_7

Bays International. (2018). Femina Brands. http://www.baysinternational.com/brands/femina-cosmetic_5

Bays international. (2018). Framesi brands. http://www.baysinternational.com/brands/framesi_8

Bays international. (2018). Janssen brands. http://www.baysinternational.com/brands/janssen_17

Bays international. (2018). Just-for-men brands. http://www.baysinternational.com/brands/just-formen_3

Bays international. (2018). Sweet-touch brands. http://www.baysinternational.com/brands/sweettouch_1

Business Recorder. (2010). Pakistan cosmetics market takes big strides. BR Research. https:// fp.brecorder.com/res/44-miscellaneous/1059-pakistan-cosmetics-market-takes-big-strides/

Daily Hunt. (2010).10 Harmful Side Effects of Makeup. https://m.dailyhunt.in/news/india/

Euromonitor. (2019). Beauty and personal care in Pakistan. https://www.euromonitor.com/beauty-and-personal-care-in-pakistan/report

Euromonitor. (2018). Market size of beauty and personal care products in Pakistan. https://www.euromonitor.com/

Kumari, P., Pandita, D., Poonia, N., \& Lather, V. (2017). Nanomaterials in Cosmetics: Regulatory, Quality \& Safety Assessment. Applied Clinical Research, Clinical Trials, and Regulatory Affairs, 4(2), 99-106.

Maithili, A., Anuradha, S., \& Nupur, M. (2015). Toxic effects of cosmetics on the users: a review. Journal of Environmental Research \& Development, 9, 900-905.

Market Research. (2019). Make-Up and Skin Care Product Market in Pakistan. https://www.marketresearch.com/Global-Research-Data-Services-v3891/Skin-Care-Product-PakistanSize-9839420/

Mohamed, H. M. (2015). Green, environment-friendly, analytical tools give insights in pharmaceuticals and cosmetics analysis. TrAC Trends in Analytical Chemistry, 66, 176-192.

Pakistan Cosmetics Manufacturers Association. (2019). An Overview of Cosmetics Industry Pakistan. http://pcma.com.pk/ 
Shaikh, A. (2018). The Business of Beauty. Aurora, Dawn. https://aurora.dawn.com/news/1143226

Tejal, P., Nishan, D., Amisha, J., Umesh, G., Desai, K. T., \& Bansal, R. K. (2013). Cosmetics and health: usage, perceptions and awareness. Bangladesh journal of medical science, 12(4), 392-397.

Zulaikha, S. R., Norkhadijah, S. I., \& Praveena, S. M. (2015). Hazardous ingredients in cosmetics and personal care products and health concern: A review. Public Health Research, 5(1), 7-15.

\section{APPENDIX}

\section{Exhibit-A-Janssen price list}

2- phase visible fading out - $6 \times 7.5 \mathrm{ml}$

$A$ control ampoules - $25 \times 2 \mathrm{ml}$

Acc rola pro age mask $10 \times 30$

Acc rola pro age mask $10 \times 50$

Aquatense moisture gel-200ml

Balancing cream $200 \mathrm{ml}$

Bio fruit gel exfoliator $-30 \mathrm{ml}$

Bio fruit gel exfoliator $-50 \mathrm{ml}$

Botanica white mask - $1000 \mathrm{~g}$

Botanica white mask - $10 \times 30 \mathrm{~g}$

Botanica white mask - $500 \mathrm{~g}$

Brightning face cleanser $-500 \mathrm{ml}$

Brightning face cleanser-200ml

Brightning face freshner $-200 \mathrm{ml}$

Brightning face freshner $-500 \mathrm{ml}$

Brightning skin complex $-30 \mathrm{ml}$

Brightning skin complex $-50 \mathrm{ml}$

C.p mela fedian cleansing powder $100 \mathrm{~g}$

Calming sensitive cream $-200 \mathrm{ml}$

Clarifying cleansing gel $-500 \mathrm{ml}$

Collagen eye contour pad (yellow)

Day vitalizer

Derma fleece collagen mask - sheet

Enzyme peeling mask $10 \times 30$

Cc cream light $30 \mathrm{ml}$ (2700)

Cc cream medium $30 \mathrm{ml}$ (2701)

Detox cream $50 \mathrm{ml}$ (2910)

Detox formula $50 \mathrm{ml}$ (2930)

$\mathrm{Ph}$ neutralizer $250 \mathrm{ml}(5710 \mathrm{p})$

Exfoliator-20 $50 \mathrm{ml}(5720 \mathrm{p})$

\begin{tabular}{|c|c|c|}
\hline 3030 & Gel mask brush & 870 \\
\hline 2770 & Gentle cleansing powder $100 \mathrm{gr}$ & 1760 \\
\hline 3630 & Hydrating gel mask (rich) - $200 \mathrm{ml}$ & 2480 \\
\hline 3800 & Immunizing skin complex - 30ml & 1980 \\
\hline 2480 & Immunizing skin complex - 50ml & 2370 \\
\hline 3080 & Intensive face scrub - $200 \mathrm{ml}$ & 2590 \\
\hline 1540 & Intensive face scrub- $50 \mathrm{ml}$ & 1600 \\
\hline 2040 & Lifting effect ampuoles $-25 \times 2 \mathrm{ml}$ & 3140 \\
\hline 8910 & Lifting vitamin c powder mask $-10 \times 30 \mathrm{~g}$ & 3300 \\
\hline 3740 & Liftning facial mini kit & 3345 \\
\hline 4900 & Man travel purse $m-610 / m-630$ & 4020 \\
\hline 2810 & Mela fadain day cream - $200 \mathrm{ml}$ & 3850 \\
\hline 1710 & Mela fadain day cream - $50 \mathrm{ml}$ & 2150 \\
\hline 1710 & Mela fadin ampoules $-25 \times 2 \mathrm{ml}$ & 3140 \\
\hline 2810 & Mild face scrub-200ml & 2480 \\
\hline 1965 & Mixing bowl-spatula & 320 \\
\hline 2920 & Night cream $-200 m l$ & 3850 \\
\hline 1525 & Night cream $-50 \mathrm{ml}$ & 2150 \\
\hline 2480 & Night replenisher $-200 \mathrm{ml}$ & 2810 \\
\hline 2810 & Normalizing fluid $25 \times 2$ & 3140 \\
\hline 280 & Ocean mineral activate $1000 \mathrm{ml}$ & 2810 \\
\hline 2260 & Ocean mineral activate $500 \mathrm{ml}$ & 1930 \\
\hline 1210 & Optimal tinted complex cream $50 \mathrm{ml}$ & 1820 \\
\hline 3630 & Perfect balancing cream $-200 \mathrm{ml}$ & 3080 \\
\hline 1650 & Perfect balancing cream $-50 \mathrm{ml}$ & 1930 \\
\hline 1650 & Phytogen dead sea black mask $10 \times 30 \mathrm{~g}$ & 3520 \\
\hline 2200 & Phytogen yellow mask & 3740 \\
\hline 2200 & Purifying mask $200 \mathrm{ml}$ & 3030 \\
\hline 4400 & Purifying tonic lotion $-500 \mathrm{ml}$ & 2810 \\
\hline 2200 & Radiant firming tonic $-200 \mathrm{ml}$ & 1820 \\
\hline
\end{tabular}




\begin{tabular}{|c|c|c|c|}
\hline Exfoliator-30 $50 \mathrm{ml}(5730 \mathrm{p})$ & 2310 & Radiant firming tonic $-500 \mathrm{ml}$ & 2750 \\
\hline Exfoliator-40 $50 \mathrm{ml}(5740 \mathrm{p})$ & 2530 & Rich eye contour cream $15 \mathrm{ml}$ & 1760 \\
\hline Exfoliator-60 $50 \mathrm{ml}(5760 \mathrm{p})$ & 2640 & Relexing massage cream $200 \mathrm{ml}$ & 2370 \\
\hline Exfoliation system cleanser $250 \mathrm{ml}(5700 \mathrm{p})$ & 2530 & Retail kit extreme white & 3630 \\
\hline Firming neck E decollete cream $50 \mathrm{ml}$ (071) & 1650 & Rich energy mask $200 \mathrm{ml}$ & 2700 \\
\hline Exfoliating powder $25 \times 1$ & 1870 & Rich eye contour cream $15 \mathrm{ml}$ & 1760 \\
\hline Extra- rich convenience cream $200 \mathrm{ml}$ & 4290 & Rich eye contour cream $30 \mathrm{ml}$ & 2420 \\
\hline Extra- rich convenience cream $50 \mathrm{ml}$ & 2860 & Sensitive creamy clenaser $-500 \mathrm{ml}$ & 2750 \\
\hline Extreme white mask $-10 \times 50 \mathrm{~g}$ & 3740 & Sensitive skin complex $50 \mathrm{ml}$ & 2640 \\
\hline Eye zone treatment $25 \times 2 \mathrm{ml}$ & 3140 & Skin excel enzyme peel $25 \times 2 \mathrm{ml}$ & 3140 \\
\hline Face guard plus $50 \mathrm{ml}$ & 2810 & Skin refining enzyme peel $200 \mathrm{ml}$ & 3470 \\
\hline Face manager (fair skin extreme kit) & 4045 & Soothing face mask - $200 \mathrm{ml}$ & 3030 \\
\hline Face spatula & 295 & Soothing gel toner $200 \mathrm{ml}$ & 2310 \\
\hline Face spatulas (25pcs) & 375 & Tinted day protection $50 \mathrm{ml}$ & 1820 \\
\hline Firming face E' neck cream - $200 \mathrm{ml}$ & 3520 & Towel gift set & 2310 \\
\hline Friut peeling ampoules $-25 \times 2 \mathrm{ml}$ & 2770 & Wakme pro white $10 \times 50 \mathrm{gm}$ & 3300 \\
\hline
\end{tabular}

\section{Exhibit B - Framesi Price list}

\begin{tabular}{|c|c|c|c|}
\hline Activator $100 \mathrm{ml}$ (all variant) & 115 & Morphosis-delux color mask $200 \mathrm{ml}$ & 1,475 \\
\hline Activator $946 \mathrm{ml}$ & 700 & Morphosis-delux color mask $250 \mathrm{ml}$ & 1,400 \\
\hline Antial tube $150 \mathrm{ml}$ & 830 & Morphosis-delux color mask $500 \mathrm{ml}$ & 2,560 \\
\hline Avan hair proctection spray & 700 & Morphosis-delux color serum $150 \mathrm{ml}$ & 1,630 \\
\hline Bustina regional conditioner $(50 \times 15 \mathrm{ml})$ & 2,915 & Morphosis-delux color shamp $1000 \mathrm{ml}$ & 2,560 \\
\hline By-black lava hair spary $400 \mathrm{ml}$ & 1,170 & Morphosis-delux color shamp $250 \mathrm{ml}$ & 1,400 \\
\hline By-black lava mega hold hair spary $500 \mathrm{ml}$ & 1,400 & Morphosis-density drops $10 \mathrm{ml}$ (12pcs) & 3,730 \\
\hline By-techno filler $100 \mathrm{ml}$ & 1,045 & Morphosis-enforcer hair mud & 1,305 \\
\hline By-voumizing spary $100 \mathrm{ml}$ & 1,045 & Morphosis-essence fluid $150 \mathrm{ml}$ & 1,630 \\
\hline By-black hair spary color protection $500 \mathrm{ml}$ & 1,400 & Morphosis-exfoliate mask $150 \mathrm{ml}$ & 1,065 \\
\hline By-dew drops & 700 & Morphosis-hand treatment $75 \mathrm{ml}$ & 445 \\
\hline By-frozen glaze $250 \mathrm{ml}$ & 880 & Morphosis-harmony shampoo $1000 \mathrm{ml}$ & 2,560 \\
\hline By-hair spray black love & 880 & Morphosis-harmony shampoo $250 \mathrm{ml}$ & 1,400 \\
\hline By-hydro gel $150 \mathrm{ml}$ & 640 & Morphosis-hi potency shampoo $1000 \mathrm{ml}$ & 2,445 \\
\hline By-bydro gel strong & 640 & Morphosis-hi potency shampoo $250 \mathrm{ml}$ & 1,400 \\
\hline By-ice wax & 1,045 & Morphosis-in force shampoo $1000 \mathrm{ml}$ & 2,445 \\
\hline By-mist hair spray $300 \mathrm{ml}$ & 930 & Morphosis-in force shampoo $250 \mathrm{ml}$ & 1,400 \\
\hline By-pearl shiner $200 \mathrm{ml}$ & 1,090 & Morphosis-multi action mask $250 \mathrm{ml}$ & 1,400 \\
\hline By-silver gel $150 \mathrm{ml}$ & 995 & Morphosis-refine mask $150 \mathrm{ml}$ & 1,066 \\
\hline By-slush gloss $50 \mathrm{ml}$ & 1,110 & Morphosis-renew fluid $150 \mathrm{ml}$ & 1,630 \\
\hline By-sparkling mouse strong & 765 & Morphosis-shock treatment kit & 4,565 \\
\hline By-sparkling mousse $200 \mathrm{ml}$ & 675 & Morphosis-sublimis argan oil $100 \mathrm{ml}$ & 1,860 \\
\hline By-wax volcanic & 1,045 & Fram color shade card - lux file (nerw) & 5,245 \\
\hline
\end{tabular}




\begin{tabular}{|c|c|c|c|}
\hline Color lover shampoo $500 \mathrm{ml}$ & 940 & Shade card-caramel 4 nuances & 1,170 \\
\hline Color lover conditioner $500 \mathrm{ml}$ & 940 & Morphosis-sun shield oil $100 \mathrm{ml}$ & 1,340 \\
\hline Color lover-hair primer eleven $125 \mathrm{ml}$ & 940 & Morphosis-technical poster & 575 \\
\hline $\begin{array}{l}\text { Color lover-volumiz bifasico liven condition- } \\
\qquad \text { er } 200 \mathrm{ml}\end{array}$ & 1,000 & Morphosis-total control shampoo $1000 \mathrm{ml}$ & 2,560 \\
\hline Color-221 & 780 & Morphosis-total control shampoo $250 \mathrm{ml}$ & 1,400 \\
\hline Decolor $b$ cream plus & 1,110 & Morphosis-velvet $100 \mathrm{ml}$ & 1,285 \\
\hline Decolor b cream tube & 880 & Option go shampoo E̋ mask $1000 \mathrm{ml}$ (twin pack) & 2,330 \\
\hline Decolor b diamond $500 \mathrm{gr}$ & 2,000 & Options-color cleanse 1 litre & 1,955 \\
\hline Decolor b no dust & 1,890 & Options-color cleanse $250 \mathrm{ml}$ & 1,066 \\
\hline Decolor b special jar & 865 & Options-deep & 1,066 \\
\hline Identity- bold up $250 \mathrm{ml}$ & 1,515 & Options-drench & 1,066 \\
\hline Identity-i.dust $4 g r$ & 1,220 & Options-extra multi move & 1,220 \\
\hline Identity-multi shape wax $100 \mathrm{ml}$ & 1,220 & Options-extreme care 1 litre & 1,955 \\
\hline Identity-power-up wax $100 \mathrm{ml}$ & 1,220 & Options-extreme care $250 \mathrm{ml}$ & 1,066 \\
\hline Identity-shine on $60 \mathrm{ml}$ & 1,170 & Options-free & 985 \\
\hline Identity- show wax $100 \mathrm{ml}$ & 1,220 & Options-free $150 \mathrm{ml}$ & 815 \\
\hline Identity-stay matte $60 \mathrm{ml}$ & 1,170 & Options-hydrate & 1,065 \\
\hline Identity-tuff hold $60 \mathrm{ml}$ & 1,170 & Options-intense & 1,065 \\
\hline Identity-xfactor $150 \mathrm{ml}$ & 1,170 & Options-liquid protein & 1,065 \\
\hline Identity-hair force & 1,140 & Options-moist-air & 1,065 \\
\hline Identity-look me $250 \mathrm{ml}$ & 1,455 & Options-multi move neutralizer $970 \mathrm{ml}$ & 1,220 \\
\hline Identity-mini flat iron & 2,445 & Options-post color $150 \mathrm{ml}$ & 1,370 \\
\hline Identity-protect it $200 \mathrm{ml}$ & 1,580 & Options-rinse & 1,065 \\
\hline Identity-stay stuk & 1,580 & Options-shampoo go $1000 \mathrm{ml}$ & 2,100 \\
\hline Identity-x-alt $150 \mathrm{ml}$ & 1,285 & Options-ultra body 1 litre & 1,955 \\
\hline Morphosis - delux color mask $1000 \mathrm{ml}$ & 2,560 & Options-ultra body $250 \mathrm{ml}$ & 1,170 \\
\hline Morphosis - delux color mask $250 \mathrm{ml}$ & 1,400 & Options-ultra violet shampoo $250 \mathrm{ml}$ & 1,170 \\
\hline Morphosis - anti ageing mask $250 \mathrm{ml}$ & 1,400 & Ossidorr- $(5,10,15,20,25)$ vol $946 \mathrm{ml}$ & 720 \\
\hline Morphosis - anti ageing shampoo $1000 \mathrm{ml}$ & 2,560 & Ossidorr-(30 \& 40) vol $946 \mathrm{ml}$ & 780 \\
\hline Morphosis - anti ageing shampoo $250 \mathrm{ml}$ & 1,400 & Ossidorr-120 ml (all variant) & 135 \\
\hline Morphosis - anti frizz intensiv serum $15 \mathrm{ml}$ & 1,860 & Protect cream $100 \mathrm{ml}$ & 780 \\
\hline Morphosis - defence gocce $10 \mathrm{ml}$ & 3,730 & Proxen-balancing shampoo & 520 \\
\hline Morphosis - density gocce $10 \mathrm{ml}$ & 3,730 & Proxen-cleans soften oil $250 \mathrm{ml}$ & 520 \\
\hline Morphosis - multi action mask $1000 \mathrm{ml}$ & 2,560 & Proxen-detoxifying serum & 520 \\
\hline Morphosis-de-stress serum $100 \mathrm{ml}$ & 1,170 & Proxen-exfoliating cream & 520 \\
\hline Morphosis-de-stress shampoo $1000 \mathrm{ml}$ & 2,560 & Proxen-fluid tonic & 520 \\
\hline Morphosis-de-stress shampoo $250 \mathrm{ml}$ & 1,400 & Proxen-fortifying mask & 520 \\
\hline Morphosis glow shampoo & 1,400 & Proxen-intensive $250 \mathrm{ml}$ shampoo & 520 \\
\hline Morphosis- refil oil $150 \mathrm{ml}$ & 1,630 & Proxen-normalizing drops & 520 \\
\hline Morphosis-sport densifying spary $100 \mathrm{ml}$ & 1,285 & Proxen-preventative mask & 585 \\
\hline
\end{tabular}


Farooqui, Qureshi, Zeeshan E Soomro

\begin{tabular}{|c|c|c|c|}
\hline Morphosis-after glow & 1,020 & Sillis baisc (silk straightening system) $150 \mathrm{ml}$ & 1,780 \\
Morphosis cubes-green & 5,224 & Supersmak $250 \mathrm{ml}$ (stain remover) & 940 \\
Morphosis cubes-orange & 5,224 & Rigenol cream jar 100ml & 220 \\
Morphosis cubes-purple & 5,224 & Rigenol cream jar $500 \mathrm{ml}$ & 1,000 \\
Morphosis cubes-silver & 5,224 & Rigenol cream tube $250 \mathrm{ml}$ & 745 \\
Morphosis cubes-yellow & 5,224 & Rigenol flacone spary $200 \mathrm{ml}$ & 1,220 \\
Morphosis-argan mask $1000 \mathrm{ml}$ & 2,445 & Rigenol protective shamp $1000 \mathrm{ml}$ & 1,340 \\
Morphosis-argan mask $250 \mathrm{ml}$ & 1,400 & Rigenol protective shamp $100 \mathrm{ml}$ & 320 \\
Morphosis-argan shampoo $1000 \mathrm{ml}$ & 2,560 & Rigenol protective shamp $250 \mathrm{ml}$ & 700 \\
Morphosis-argan shampoo $250 \mathrm{ml}$ & 1,400 & Rigenol restructuring shamp $1000 \mathrm{ml}$ & 1,340 \\
Morphosis-balancer hair mud & 1,305 & Rigenol restructuring shamp $100 \mathrm{ml}$ & 320 \\
Morphosis-defence drops $10 \mathrm{ml}(12 \mathrm{pcs}$ ) & 3,260 & Rigenol restructuring shamp $250 \mathrm{ml}$ & 700 \\
Morphosis-delux color mask $1000 \mathrm{ml}$ & 2,800 & Rigenol serum (15ml x $6 \mathrm{cs}$ ) & 1,330 \\
\hline
\end{tabular}

\section{Exhibit C Femina-price list}

\begin{tabular}{cc}
\hline Eye liner & 195 \\
Eye pencil & 45 \\
Lippencil & 45 \\
Lipstick & 165 \\
Long lash mascara & 200 \\
Nail polish & 100 \\
Volumizing mascara & 200 \\
Eye shade & 120 \\
Paint stick & 520 \\
Twin cake & 520 \\
Sparkling blusher & 690 \\
Foundation real fitting & 750 \\
Femina 6 pieces brush with pouch & 1,440 \\
Trwin cake riffle & 345 \\
\hline
\end{tabular}

\section{Exhibit D-Kryolin-price list}

\begin{tabular}{|c|c|c|c|}
\hline Tv stick & 1,220 & Brush-3616 & 640 \\
Aqua color wet medium & 1,220 & Brush-3606 & 345 \\
Dry cake & 1,220 & Brush-3504 & 345 \\
Cake liner & 670 & Brush-3520 & 525 \\
Eye shadow & 890 & Brush-3612 & 610 \\
Satin powder & 720 & Brush-3828 & 1,045 \\
Eye shadow (compact) riffle & 560 & Brush-3807 & 525 \\
Cake liner metalic \# 1111 & 840 & 14 pcs brush kryolan empty pouch & 830 \\
Non latex foam \# 1447 & 280 & Eye shade-base-9095 & 640 \\
\hline
\end{tabular}




\begin{tabular}{|c|c|c|c|}
\hline Latex foam \# 1449 & 220 & interferenz -rainbow \# 1316 & 2,720 \\
\hline Cake eye liner sealor & 940 & Aqua color liq & 1,745 \\
\hline Cake eye liner (inbox) & 650 & Osp remover art\# 2037 & 1,045 \\
\hline Mascara-inbox \# 1351 & 880 & Brush cleans art\# 3491 & 700 \\
\hline Mascara (box)\# 1352 & 1,725 & Glamour glow & 2,780 \\
\hline Loose powder & 1,550 & Glamour sparkling & 1,220 \\
\hline Ultra foundation stick & 2,440 & Glanze liquid & 2,915 \\
\hline Ultra fluid foundation $30 \mathrm{ml}$ & 1,500 & Micro found liq & 3,890 \\
\hline Eye liner (liquid) black art \# 5320 & 900 & Micro silk powder & 3,000 \\
\hline Mascara (liquid) black art \# 1353 & 880 & Liquid bright & 2,915 \\
\hline Polyester glitter & 670 & Aqua color metalic \# 1112 & 1,170 \\
\hline Interferenz & 1,170 & Derma fixing powder (l) $60 \mathrm{gr}$ & 2,220 \\
\hline Eye lash & 110 & Derma color-compact & 2,440 \\
\hline Anti shine powder & 1,720 & Matt perfect $40 \mathrm{ml}$ & 2,550 \\
\hline Lip glisser & 315 & Makeup corrector & 1,170 \\
\hline Ultra under base \# 9099 & 2,000 & Derma fixing spray (72290) & 1,780 \\
\hline Ultra makeup base \# 9190-weiss & 1,745 & Gel maskbrush & 1,170 \\
\hline Brush-1711 & 1,050 & Sprit gum remover mme mild \# 2038 & 1,400 \\
\hline Brush-1712 & 560 & Case makeup trolly \# 7801 & 21,820 \\
\hline Brush-1715 & 940 & Makeup remover hydro $100 \mathrm{ml}$ & 1,400 \\
\hline Brush-1716 & 440 & Deck stif conselar & 815 \\
\hline Brush-3708 & 390 & Eye lash adhesive art\# 5340 & 700 \\
\hline Brush-3710 & 440 & Derma puff- $m$ & 280 \\
\hline Brush-3712 & 610 & Derma puff-p & 315 \\
\hline Brush-3714 & 815 & Kajal pencil & 700 \\
\hline Brush-3716 & 1,075 & Glatzon - l $25951000 \mathrm{ml}$ & 23,310 \\
\hline Brush-3806 & 390 & Cleansing cream - 9602 & 810 \\
\hline Brush-3808 & 500 & Liquid latex 500ml\# 2543 & 9,320 \\
\hline Brush-3810 & 500 & Liquid latex $1000 \mathrm{ml} \# 2544$ & 17,480 \\
\hline Brush-3812 & 610 & Derma mineral powder & 2,100 \\
\hline Brush-3814 & 1,355 & Nose putty art\#1400 & 1,890 \\
\hline Brush-3816 & 890 & M.f.glamour glow & 2,830 \\
\hline Brush-4221 & 330 & High gloss brilliant lip gloss & 1,500 \\
\hline Brush-4222 & 295 & Glamour glow (riffile) & 525 \\
\hline Brush-1717 & 675 & High diffination micro shade & 1,400 \\
\hline Brush pouch empty & 410 & Eye shade applicator brush & 205 \\
\hline Brush-1364 & 410 & Foundation brush & 765 \\
\hline
\end{tabular}


Exhibit E-Just for Men - Price list

\begin{tabular}{cc}
\hline Gel-dark brown & 745 \\
Gel-light brown & 745 \\
Gel-medium brown & 745 \\
Gel-real black & 745 \\
Hair color-dark brown & 745 \\
Hair color-light brown & 745 \\
Hair color-medium brown & 745 \\
Hair color-real black & 745 \\
Restoria cream 150ml & 525 \\
Restoria cream 250ml & 700 \\
\hline
\end{tabular}

